\title{
Long-term risks of metal contaminants in drinking water: a critical appraisal of guideline values for arsenic and vanadium
}

\author{
Riccardo Crebelli and Paola Leopardi \\ Dipartimento di Ambiente e Connessa Prevenzione Primaria, Istituto Superiore di Sanità, Rome, Italy
}

\begin{abstract}
Metal contaminants in drinking water represent a relevant health issue in several areas of the world. In Italy, because of the geological features of the territory, high arsenic and vanadium are frequently reported in ground waters in concentrations above current guideline values. The implications for public health of the presence of contaminants above their legal limit are directly related to the biological basis of the guideline value. In the case of arsenic there are still major uncertainties in the mechanism of carcinogenesis which prevent a precise evaluation of long-term risks. Thus, the guideline value endorsed in the European Community $(10 \mu \mathrm{g} / \mathrm{L})$ has to be considered as a pragmatic tool rather than a quality objective, bearing in mind that "every effort should be made to keep concentrations as low as reasonably possible" (WHO, 2011). A reverse situation holds for vanadium, for which a strict national limit $(50 \mu \mathrm{g} / \mathrm{L})$ was previously proposed in consideration of data gaps, and for which new evidence indicated a less stringent health-based limit.
\end{abstract}

Key words: drinking water, chemical hazards, guideline values, arsenic, vanadium.

Riassunto (Rischi a lungo termine associati alla presenza di metalli nell'acqua potabile: una disamina sugli attuali valori limite di arsenico e vanadio ). La presenza di contaminanti inorganici nell'acqua potabile rappresenta un importante problema sanitario in varie aree del mondo. In Italia, alte concentrazioni di arsenico e vanadio, dovute alle caratteristiche geologiche del territorio, sono state segnalate in acque sotterranee usate per l'approvvigionamento idrico. Le conseguenze di ordine sanitario della presenza di contaminanti nell'acqua a concentrazioni superiori al limite legale dipendono direttamente dalle basi biologiche su cui poggia il valore stesso. Nel caso dell'arsenico, le incertezze tuttora esistenti sul meccanismo d'azione impediscono una stima precisa del rischio a basse dosi, per cui appare opportuno considerare il valore corrente come un obiettivo minimo, tenendo presente la necessità di ridurre l'esposizione umana al valore più basso realizzabile. Al contrario, nel caso del vanadio una rivalutazione sulla base di nuove evidenze scientifiche può indicare un valore limite meno stringente di quello precedentemente indicato a livello nazionale sulla base di conoscenze incomplete.

Parole chiave: acqua potabile, rischio chimico, valori guida, arsenico, vanadio.

\section{INTRODUCTION}

Drinking water quality has a heavy impact on human health. A recent assessment of major health risk factors attributed over two million deaths to unsafe water, which represents the leading environmental risk factor on a global scale [1]. The geographic distribution of mortality and burden of diseases related to water quality shows substantial differences between high-, middle- and low-income countries. Overall, more than $99 \%$ of death attributed to unsafe water occur in developing countries, where children represent the most susceptible age group [1]. The geographic and demographic patterns of risk highlight the prevailing role played by microbiological quality in determining water safety. Indeed, the presence of pathogens is still the most critical factor in determining water quality [2], despite water disinfection represented one of most significant advances of public health in last century. Chemical risk factors, however, may assume greater relevance in developed countries, where water supply is characterized by high standards of microbiological safety. Among chemical factors, regulated [2] and newly emerging [3] disinfection by-products have received major consideration as potential genotoxic and carcinogenic hazards. In addition to disinfection by-products, improvements in analytical techniques allow to identify a number of organic micropollutants (e.g. plasticizers, drugs, persistent organic pollutants), which represent a new challenge for the assessment and management of health risk associated with drinking water [4]. However, it is inorganic contaminants of geological origin which still raise the greatest concern, especially in selected geographical areas. In Italy, arsenic and vanadium have received major consideration 
for their biological activity and potential health impact, as well as for the frequent occurrence in groundwater at levels above their parametric values. In this paper the biological basis of the European guideline values for arsenic and vanadium in drinking water, and the implications for public health of the derogation from these limits, are briefly discussed.

\section{ARSENIC}

Basic aspects of chemistry, occurrence and biological activity of arsenic compounds, with special reference to carcinogenesis, are briefly summarized in the following subchapters. More detailed information can be retrieved from recently published reviews on arsenic exposure, toxicology and mode of action [5-7].

\section{Chemistry, occurrence and human exposure}

Arsenic (As) is a metalloid widely present in the earth's crust. The most common oxidation states are $+3\left(\mathrm{As}^{+3}\right.$ or arsenite $)$ and $+5\left(\mathrm{As}^{+5}\right.$ or arsenate $)$. Trivalent arsenicals are generally more toxic than pentavalent ones, due to their reactivity with sulphur containing compounds and the generation of reactive oxygen species (ROS). Both arsenic compounds can be found in inorganic and organic forms, the latter with lower or no toxicity. Concentrations of arsenic in groundwater, frequently the main source of drinking water, are usually less than $10 \mu \mathrm{g} / \mathrm{L}$, but they can reach $5000 \mu \mathrm{g} / \mathrm{L}$ in some areas $[8,9]$. Lower concentrations of arsenic are generally found in surface waters. Essentially all arsenic in drinking water is present as inorganic As (mainly $\mathrm{As}^{+5}$ ).

Diet is the main sources of exposure to arsenic compounds for the general population, with fish and seafood, cereals and cereal products as main contributors. Recently the European Food Safety Authority (EFSA) has estimated that in Europe average consumer intake of inorganic arsenic range from 0.13 to $0.56 \mu \mathrm{g} / \mathrm{kg}$ b.w./day (lower and upper bound) [9]. Drinking water may represent the major contributor to dietary exposure to inorganic arsenic in areas with high natural levels of arsenic in groundwater. This is a major source of exposure worldwide, given that an estimated 160 million people live in regions with naturally elevated levels of arsenic in drinking water due to the presence of arsenic-rich geological formations and/or anthropogenic activities [2].

\section{Metabolism and toxicokinetics}

In humans inorganic arsenic is rapidly absorbed after ingestion, and subject to biotransformation which includes the reduction of pentavalent arsenate to trivalent arsenite, requiring reduced glutathione as electron donor, and the oxidative methylation of arsenite by $\mathrm{As}^{+3}$-methyltransferase (As3mt) using S-adenosyl-methionine (SAM) as methyl group donor. Methylation of inorganic arsenic facilitates its excretion from the body. Arsenic toxicity in mammalian species largely depends on the rate of methylation of inorganic arsenic by liver As3mt [5], and by the rate of transport of arsenic metabolites across liver cell membrane by specific hepatic transporters. Major qualitative and quantitative inter-species differences in arsenic methylation capacity have been reported: higher activity has been observed in dog, rat and monkey compared to rabbit, mouse and humans, ascribed to the higher As3mt expression in those species [5]. Within the human species, the differential expression of As3mt associated with the AS3MT gene polymorphism plays a key role in determining the inter-individual variation in the susceptibility to arsenic induced toxicity and carcinogenicity [10].

\section{Effects in humans}

There is a strong body of evidence linking arsenic intake with a variety of health problems, from acute toxicity to chronic diseases [2]. The World Health Organization - International Agency for Research on Cancer (WHO-IARC) classifies arsenic as a known (Group 1) human carcinogen [2]. The main adverse effects reported to be associated with long term ingestion of inorganic arsenic in humans are skin lesions, cancer, developmental toxicity, neurotoxicity, cardiovascular diseases, abnormal glucose metabolism, and diabetes. Neurotoxicity is mainly reported with acute exposure from deliberate poisoning or suicide, or at high concentrations in drinking water.

Of the various sources of arsenic in the environment, long-term exposure to arsenic in drinking water is likely to pose the greatest threat to human health, and the occurrence of arsenic in drinking water has been recognized as a major public health concern in several regions of the world over the past decades [2]. Most evidence linking arsenic in drinking water with elevated cancer risk of internal organs comes from ecological studies in populations in Taiwan, Argentina, and Chile with high arsenic exposures from underground wells. Dose-related increases in the incidence of lung, urinary bladder and kidney cancers were consistently reported in population groups drinking water with arsenic concentrations above $150-200 \mu \mathrm{g} / \mathrm{L}[2,8,9]$. At lower levels of exposure $(<100 \mu \mathrm{g} / \mathrm{L})$, the available evidence is less robust and complicated by possible misclassification of study subjects, due to the difficulty in estimating past exposure, and by the limited size of most studies which make the interpretation of results more challenging [11].

\section{Mode of action in carcinogenesis}

Although the carcinogenicity of arsenic in humans has been known for more than 100 years, there is no definitive understanding of its mechanism of action for this effect. This gap in knowledge is partly due to the lack, for a number of years, of an animal model for carcinogenicity, as well as to the complex genotoxic profile and biotransformation of arsenic, and to the multiplicity of effects of arsenic compounds in biological systems. 
Modes of action in arsenic-induced carcinogenicity have been extensively discussed in several recent reviews [6, 7, 12-16]. Briefly, induction of genetic damage, oxidative damage, epigenetic alterations, interference with DNA damage repair or cancer related gene proteins, have been considered as potential mechanisms, not mutually exclusive, underlying arsenic carcinogenicity. Even though the specific role of each of the proposed mechanism has not yet been disentangled, it is noteworthy that for all of them, including the induction of genetic damage, a threshold mechanism can be anticipated. As discussed later, this consideration is pivotal in risk characterization, when risk at low doses has to be extrapolated from high dose studies.

Concerning genetic damage, in particular, no direct binding or interaction of arsenic with DNA is observed. Thus, DNA damage observed in vitro and in vivo following exposure to inorganic arsenic (mainly arsenite) is attributed to indirect mechanisms such as oxidative stress mediated by increased levels of reactive oxygen species and reactive nitrogen species, and to the interference of arsenic with DNA repair and DNA damage response. The latter mechanism is also proposed to be involved in the distinct co-mutagenic and co-carcinogenic activity of arsenic [9].

\section{Risk characterization}

Several agencies have formulated quantitative estimates of cancer risk for arsenic in drinking water. Data from epidemiological studies in areas with high levels of arsenic contamination in well water were used in most cases.

The WHO/FAO Joint Expert Committee on Food Additives (JECFA) first derived a provisional maximum tolerable daily intake (PTDI) for inorganic arsenic of $2 \mu \mathrm{g} / \mathrm{kg}$ b.w. Based on the results from a small study in Nova Scotia, in its twenty-seventh meeting JECFA concluded that "On the basis of the data available the Committee could arrive at only an estimate of $0.002 \mathrm{mg} / \mathrm{kg} \mathrm{b.w}$. as a provisional maximum tolerable daily intake for ingested inorganic arsenic." This conclusion was based on the evidence of general toxicity (arsenicism) associated with water supplies containing arsenic concentrations $\geq 1 \mathrm{mg} /$ L [17]. Arsenic was again considered by JECFA at its $33^{\text {rd }}$ meeting, when the previous evaluation was confirmed and a provisional tolerable weekly intake (PTWI) of $15 \mu \mathrm{g} / \mathrm{kg}$ b.w. for inorganic arsenic established, "with the clear understanding that the margin between the PTWI and intakes reported to have toxic effects in epidemiological studies was narrow" [18]. The PTWI of $15 \mu \mathrm{g} / \mathrm{kg}$ b.w. originally set by JECFA was later criticized by the EFSA [9], and withdrawn by JECFA in 2011 [19]. In this recent JECFA opinion, data from a large prospective study in north-eastern Taiwan residents, for whom arsenic concentration in drinking water was known, were modelled to calculate the benchmark dose $\left(\mathrm{BMD}_{0.5}\right)$ associated with $0.5 \%$ increase of cancer over back- ground. The lowest calculated BMDL0.5 value (lower $95 \%$ percentile of $\mathrm{BMD}_{0.5}$ ) was $3.0 \mu \mathrm{g} / \mathrm{kg}$ b.w. for increased incidence of lung cancer [19]. JECFA stated that, as the new $\mathrm{BMDL}_{0.5}$ was in the same region of the previous PTWI, this was withdrawn. It is noted, however, that BMDL and PTWI (or PTDI) have a different toxicological significance, given that BMDL is associated with a low, but not negligible, excess cancer risk.

In the United States, the Environmental Protection Agency (US EPA), based on large drinking water studies in the Taiwan population in which a doserelated increase of skin lesion was reported, using the Armitage-Doll linearized multistage model estimated for skin cancer an oral slope factor of $1.5 \mathrm{x}$ 10-3 for $1 \mu \mathrm{g} / \mathrm{kg}$ b.w./day [20]. From this slope factor, the risk of skin cancer associated to an arsenic concentration of $10 \mu \mathrm{g} / \mathrm{L}$ is calculated to be $5 \times 10^{-4}$ for an adult weighing $70 \mathrm{~kg}$ and consuming $2 \mathrm{~L}$ of water/day.

Other quantitative estimates of cancer risk have been formulated by the US National Research Council [21], Health Canada [22] and, more recently, by the European Food Safety Authority [9]. In its opinion on arsenic in food, EFSA modelled dose-response data from several epidemiological studies to determine the benchmark dose associated with a $1 \%$ extra risk of developing lung, bladder, and skin cancer. A range of $\mathrm{BMDL}_{1}$ was identified, from 0.3 to $8 \mu \mathrm{g} / \mathrm{kg}$ b.w. $/$ day, the lowest value being for lung cancer. Considering the estimated dietary exposure to arsenic in Europe, calculated through an extensive survey of arsenic concentrations in food commodities, EFSA concluded that there was no or little margin of exposure and that a risk for consumer could not be excluded, and recommended that dietary exposure to inorganic arsenic be reduced [9].

\section{Guideline value for drinking water}

In Europe, quality standards for water intended for human consumption are established by the Drinking Water Directive 98/83/EC [23]. With the purpose to protect human health, the Directive sets maximum values, not to be exceeded, for a series of chemical parameters (Annex I, part B.), based on the World Health Organisation's Guidelines for drinking water quality and the opinion of the Commission's Scientific Advisory Committees. The guideline value for arsenic set out in Directive 98/83/EC is $10 \mu \mathrm{g} / \mathrm{L}$, the same value indicated in the WHO Guidelines in 1993 [24]. Such value was derived by WHO from the previously established JECFA PTWI of $15 \mu \mathrm{g} / \mathrm{kg}$ b.w., allocating $20 \%$ of the PTWI to the consumption of drinking water [24].

At present, the adequacy of the guideline value indicated in the Drinking Water Directive to "protect human health from the adverse effects of any contamination", as stipulated in Article 1, can be debated. In fact, even though the guideline value of $10 \mu \mathrm{g} / \mathrm{L}$ was reiterated by WHO in 2011 [25], a cautionary note has been introduced in the last edition of Guidelines 
for drinking water quality. When discussing the basis for deriving the guideline value for arsenic, WHO noted that there was an overwhelming evidence of the causal relationship between consumption of elevated levels of arsenic through drinking water and the development of cancer at several sites, while there was considerable uncertainty over the mechanism of carcinogenicity and the shape of the doseresponse curve at low intakes, and that the guideline value of $10 \mu \mathrm{g} / \mathrm{L}$ was provisionally retained "in view of the significant uncertainties surrounding the risk assessment for arsenic carcinogenicity, the practical quantification limit in the region of 1-10 $\mu \mathrm{g} /$ litre and the practical difficulties in removing arsenic from drinking-water". Thus, the guideline value pragmatically indicated by WHO is not to be interpreted as a quality objective, given that, as stated in the same document, "every effort should be made to keep concentrations [of arsenic in drinking water] as low as reasonably possible" [25]. The latter consideration calls into question the possibility to grant temporary derogations to the guideline value, as requested - and obtained - by Italy in previous years.

Temporary derogation from the guideline values listed in Annex I can in fact be granted to Member States, provided that water supply cannot be maintained in any other reasonable way and that such derogation does not constitute a potential danger to human health (Article 9). In Italy, due to the diffuse presence of sedimentary deposits deriving from volcanic rocks, groundwater used for drinking water supply is frequently contaminated by arsenic concentrations above the guideline value. For this reason, a derogation up to $50 \mu \mathrm{g} / \mathrm{L}$ was allowed in 20022008, lowered to $20 \mu \mathrm{g} / \mathrm{L}$ for the period 2010-2012. Recently, following a request of the EU Directorate General for Health and Consumers, the Scientific Committee on Health and Environmental Risks (SCHER) has adopted an opinion on the potential danger to human health from the derogation on some parameters of the Drinking Water Directive 98/83/EC [26]. Concerning arsenic, the SCHER noted that recent meta-analyses of epidemiological data indicated a more than proportional decrease of cancer risk at low doses, supported by mechanistic considerations on the lack of DNA reactivity, and that no unambiguous evidence of excess risk was available for exposure at $<100 \mu \mathrm{g} / \mathrm{L}$. Based on these considerations, the SCHER concluded that the available information indicated that the requested derogation might only induce a very low additional tumour risk, probably less than 1/1 000000 , much less then that predicted by linear extrapolation [26].

Overall, a number of data gaps still preclude the possibility of a reliable characterization of the risk posed by arsenic in drinking water, and to set sound health-based reference values. The first data gaps concern the overall dietary exposure to inorganic arsenic, to which other food items contribute differently depending on dietary habits, and the almost complete absence of data on speciation. However, it is the lack of a comprehension of the mechanism of carcinogenicity which does not allow to develop, and apply, biologically-based models for low dose response extrapolation, providing guidance to opt between threshold or non-threshold mechanisms and to choose among the multiplicity of existing low dose extrapolation models. For the time being it can be convenient to consider the current guideline value as a pragmatic tool for risk management, and to keep in mind that at such concentration level the margin of exposure (viz. the distance from the effective concentration) may be small or even absent, as suggested by the EFSA [9], and that given the existing uncertainties human exposure to arsenic should be as low as reasonably achievable [25].

\section{VANADIUM \\ Chemistry, occurrence and human exposure}

Vanadium is a trace element widely distributed in the earth's crust at an average concentration of approximately $100 \mathrm{mg} / \mathrm{kg}$. Vanadium exists in different oxidation states, the most common being $+3,+4$, and +5 . Pentavalent vanadium is chemically most stable, and it represents the most toxic form [27].

Food is the main source of exposure to vanadium for the general population, with an estimated dietary intake of the order of few tens of micrograms per person per day [28]. Drinking water contributes to a lesser extent, as concentrations of vanadium in drinking water generally do not exceed few micrograms per liter. However, considerably higher concentrations (above $100 \mu \mathrm{g} / \mathrm{L}$ ) are recorded in some water supplies, notably in groundwater from volcanic areas as consequence of the leaching from vanadium rich rocks [29].

\section{Toxicokinetics and biological activity}

The absorption rate of vanadium compounds after ingestion depends on their solubility and chemical nature. In general, however, vanadium is poorly absorbed from the gastrointestinal tract and mainly eliminated in faeces. Once absorbed, vanadium is rapidly transported by blood circulation to various tissues: the highest concentrations are initially found in kidneys, liver, and lungs, while muscles and bone represent long-term storage sites. Pentavalent vanadium predominates in extracellular fluids, whereas the tetravalent form is the most common intracellular one [28].

Vanadium in its different oxidation states is able to exert a variety of biological effects. Many of these result from the generation of reactive oxygen species during the one-electron reduction $\mathrm{V}^{+5}$ to $\mathrm{V}^{+4}$, with subsequent DNA damage, enzyme inhibition, altered signal transduction and gene expression [30].

\section{Toxicology}

Chemical form, oxidation status, and route of exposure play a key role in determining the degree of toxicity of vanadium compounds. Orally adminis- 
tered vanadium compounds (sodium and ammonium metavanadate, sodium orthovanadate, vanadyl sulphate) have been reported to produce adverse effects in kidney, spleen and lungs of rodents, to raise blood pressure in rats, and to elicit reproductive and developmental toxicity in rats and mice [31]. In humans, mild toxic effects (gastrointestinal discomfort) have been reported in subject taking high vanadium doses as food supplements [31]. Only limited oral carcinogenicity studies in rodents are available, from which no conclusion can be drawn. Similarly, no conclusion on oral carcinogenicity can be drawn from a NTP inhalational study with vanadium pentoxide [32].

A number of studies have been performed to investigate the genotoxic potential of vanadium compounds. As these studies have particular relevance for risk assessment, also in consideration of the lack of adequate carcinogenicity studies, they are briefly illustrated herein. Overall, the available results indicate that both pentavalent and tetravalent vanadium are clearly genotoxic in test systems in vitro, where induction of DNA strand breaks, chromosome damage and altered chromosome segregation were observed [31]. Based on current knowledge of chemistry of vanadium compounds, these effects are attributed to indirect mechanisms, such as the generation of reactive oxygen species through a Fenton-like reaction rather than to a direct interaction with DNA [31]. Consequently, the relevance of these in vitro findings to the in vivo situation is not established. The genotoxic hazard posed by the oral intake of pentavalent and tetravalent vanadium was further investigated in mouse studies specifically designed to characterize the hazard of vanadium in drinking water [33, 34]. These studies demonstrated that, following repeated administration through drinking water, only pentavalent vanadium (vanadate) is able to elicit some genotoxicity in vivo, and that this effect is restricted to high dose levels. Assuming a threshold mechanisms, as supported by mechanistic considerations on the genotoxicity of vanadium compounds [31], in view of the wide margin between the minimum concentrations of vanadate genotoxic in vivo under experimental conditions and the levels of vanadium compounds occurring in drinking water, the authors concluded that vanadium in drinking water does not raise a genotoxic concern $[33,34]$.

\section{Previous evaluations}

A detailed evaluation of available toxicological data on vanadium compounds was performed by the European Food Safety Authority (EFSA) with the aim of establishing a tolerable upper intake level (UL) of vanadium [31]. However, EFSA noted that the available subchronic and developmental oral toxicity studies in rats did not allow the derivation of a no-observed-adverse-effects level (NOAEL), and that no adequate evaluation of the carcinogenic potential of vanadium by oral exposure could be made. Therefore EFSA concluded that a UL could not be established, even though noted that the normal human daily intake of vanadium was at least three orders of magnitude lower than the lowest dose reported to produce adverse effects in rats [31].

A different approach was adopted overseas, where reference values were mainly based on human data. In this respect, the Agency for Toxic Substances and Disease Registry (ATSDR) derived an intermediateduration oral MRL (minimal risk level) of $10 \mu \mathrm{g}$ vanadium $/ \mathrm{kg} /$ day, based on a NOAEL for hematological and blood pressure effects in humans exposed to vanadyl sulfate for 12 weeks [35]. A daily intake of 7 $\mu \mathrm{g} / \mathrm{kg}$ b.w. was derived by the EPA as reference dose (RfD), viz. the daily exposure level without appreciable risk over a lifetime, based on gastrointestinal disturbance (intestinal cramping and diarrhoea) observed in human studies [36].

\section{Guideline value for drinking water}

As mentioned above, drinking water is not a major source of exposure to vanadium compounds worldwide. Thus, so far vanadium has not specifically been considered by WHO in its Drinking water guidelines, and no guideline value is indicated in the European Drinking Water Directive (98/83/EC). Yet, elevated concentrations of vanadium in drinking water have been detected in some regions, which call at least for a local regulation. In Italy, the Superior Council of Health in 1995 indicated as a limit value of vanadium in drinking water the concentration of $50 \mu \mathrm{g} / \mathrm{L}$ [37]. This recommendation was based on an early US EPA Health Advisory, taking into account the limitations of the toxicological database available at that time. To fill this data gap further laboratory studies, and an epidemiological survey of populations resident in areas with high vanadium in drinking water, were recommended [37].

In view of the inability to respect the $50 \mu \mathrm{g} / \mathrm{L} \mathrm{limit}$ by water distribution systems serving large population groups, especially in the Etnean area in Sicily, and of the lack of evidence of overt toxicity, the limit value was provisionally raised by the Superior Council to $120 \mu \mathrm{g} / \mathrm{L}$ in 2000 . This decision was based on a positive opinion of the Istituto Superiore di Sanità, in which however uncertainties on the genotoxic hazard of oral vanadium were noted and further experimental studies recommended. In the framework of the activities ensuing from these recommendations, the oral genotoxicity studies quoted above $[33,34]$ were carried out. Based on the results obtained, it can be concluded that oral vanadium does not represent a genotoxic hazard, and consequently that an acceptable human exposure level can be set using a threshold approach.

As mentioned above, EFSA failed to establish a UL for vanadium, because of the difficulty in identifying the pivotal study to be used as point of departure, and because of lack of information on carcinogenicity [31]. Concerning the latter, based on the result of the in vivo studies mentioned above 
$[33,34]$, it can be ruled out that vanadium can act as a genotoxic carcinogen. Thus, no carcinogenic threat is expected for low dose vanadium in drinking water, as non-genotoxic carcinogenicity, which in principle cannot be ruled in the absence of long term studies, in any case is only elicited at high, toxic doses. Concerning the selection of the pivotal study, a critical weight was given by EFSA to early subchronic toxicity and reproduction toxicity studies, performed in one laboratory only, reporting adverse effects in rats at doses as low as $0.8 \mathrm{mg} / \mathrm{kg}$ b.w. $[38,39]$. Yet, a closer view to these publications highlights severe limitations in data reporting and interpretation which casts doubts on their relevance for risk characterization. Concerning the subchronic toxicity study [38], according to the author "... concentrations of 5,10 and $50 \mathrm{ppm}\left(\mathrm{NaVO}_{3}\right)$ were generally well tolerated during the 3-month period ... there were mild histological changes in spleen, lungs and kidneys of all the treated animals, more evident in the animals receiving the highest concentration of $\mathrm{NaVO}_{3}$.". In the absence of any other information on severity and incidence of the lesions detected, no reliable NOAEL can be derived from this study. The same group later reported a decreased body weight gain in rat pups nursed by vanadium-treated mothers [39]. Even though this finding was interpreted as a possible evidence of developmental toxicity, it can be noted that such conclusion lacks of biological plausibility, because based on the limited uptake of oral vanadium and its toxicokinetics [27], no or at most trace amounts of the element are expected in mother's milk. Thus, both studies have to be considered "not reliable" according to Klimisch criteria [40], and not to be taken into account for human risk assessment.

Despite the difficulties highlighted in the EFSA opinion, in view of the high levels of vanadium present in some groundwater serving important water supplies, and of the difficulties in removing efficiently vanadium from drinking water, there is a practical need for a biologically-based guideline value for this element. In this respect, in order to manage a few critic local situations occurring in different areas of the national territory, the Italian Ministry of Health has recently proposed a new parametric value of $140 \mu \mathrm{g} / \mathrm{L}$ [41], derived from a chronic toxicity study in rats receiving sodium metavanadate drinking water during a lifetime [42]. The limit value, referred to an adult weighing $60 \mathrm{~kg}$ and drinking $2 \mathrm{~L}$ water per day, was derived from a lowest observed adverse effect level (LOAEL) of $1.5 \mathrm{mg} / \mathrm{kg}$ b.w., applying a further safety factor of 3 to the 100 default value, and allocating $20 \mu \mathrm{g}$ of vanadium to food intake. It is noteworthy that this concentration limit, derived from experiments on sodium metavanadate, the most toxic form, include all vanadium compounds, including the least toxic as tetravalent vanadium. This adds a further margin to the default safety factors incorporated in human risk assessment. This additional factor, related to vanadium speciation, is particularly relevant for drinking water, where only a fraction of total vanadium is in the highest oxidation status [27]. It is advisable that this, or another common guideline value, be soon endorsed at the Community level.

\section{CONCLUSIONS}

Metal contaminants in drinking water still represent a relevant health issue in several areas of the world. In particular, the presence of high arsenic and vanadium in groundwater, usually linked to the geological characteristics of the territory, is a challenging task for risk managers, especially when alternative sources of water for human consumption are not available. In these circumstances the definition of sound, biologically-based guideline values acquires major relevance, as guideline values may represent the key tool for the efficient management of environmental threats, in principle allowing the best protection of human health with the minimum waste of material resources. As discussed in this report, at present internationally agreed guideline values for arsenic and vanadium in drinking water are not available, or subject to considerable debate. A re-assessment of the existing limit values, or the definition of new ones, based on stateof-the art science can thus be considered a priority issue in the environmental health agenda.

\section{Conflict of interest statement}

No financial interest is declared. The authors were co-authors of two of the publications quoted [33,34], performed within a scientific cooperation between Istituto Superiore di Sanità and Azienda Consortile Servizi Etnei (A.CO.S.ET) in the framework of an ad hoc action plane coordinated by the Ministry of Health (2000-2004)

Submitted on invitation.

Accepted on 24 September 2012.

\section{References}

1. World Health Organization. Global health risks. Mortality and burden of disease attributable to selected major risks. Geneva: WHO; 2009.

2. International Agency for Research on Cancer. IARC monographs on the evaluation of carcinogenic risks to humans. Volume 84. Some drinking-water disinfectants and contaminants, including arsenic. Lyon: IARC; 2004.

3. Richardson SD, Plewa MJ, Wagner ED, Schoeny R, Demarini

DM. Occurrence, genotoxicity, and carcinogenicity of regulated and emerging disinfection by-products in drinking water: a review and roadmap for research. Mutat Res 2007;636:178242.

http://dx.doi.org/10.1016/j.mrrev.2007.09.001

4. Levi Y. Challenges in the assessment and managment of health risks associated withemerging water micropollutants. Bull Acad Natl Med 2009;193:1331-40; discussion 1340-4. 
5. Hughes MF, Beck BD, Chen Y, Lewis AS, Thomas DJ. Arsenic exposure and toxicology: a historical perspective. Toxicol Sci 2011;123:305-32.

http://dx.doi.org/10.1093/toxsci/kfr 184

6. Kitchin KT. Recent advances in arsenic carcinogenesis: modes of action, animal model systems, and methylated arsenic metabolites. Toxicol Appl Pharmacol 2001;172:249-61. http://dx.doi.org/10.1006/taap.2001.9157

7. Kitchin KT, Conolly R. Arsenic-induced carcinogenesis-oxidative stress as a possible mode of action and future research needs for more biologically based risk assessment. Chem Res Toxicol 2010;23:327-35. http://dx.doi.org/10.1021/tx900343d

8. United States Environmental Protection Agency (US EPA). Integrated risk information system (IRIS) on arsenic. Washington, DC: National Center for Environmental Assessment, Office of Research and Development; 2001.

9. European Food Safety Authority (EFSA). Panel on contaminants in the food chain (CONTAM); scientific opinion on arsenic in food. EFSA $J$ 2009;7:1351.

10. Agusa T, Fujihara J, Takeshita H, Iwata H. Individual variations in inorganic arsenic metabolism associated with AS3MT genetic polymorphisms. Int J Mol Sci 2011;12:2351-82. http://dx.doi.org/10.3390/ijms12042351

11. Cantor KP, Lubin JH. Arsenic, internal cancers, and issues in inference from studies of low-level exposures in human populations. Toxicol Appl Pharmacol 2007;222:252-7. http://dx.doi.org/10.1016/j.taap.2007.01.026

12. Hartwig A, Schwerdtle T. Arsenic-induced carcinogenicity. New insights in molecular mechanism. In: Hadjiliadis $\mathrm{N}$, Sletten E (Eds). Metal-complex DNA interactions. John Wiley \& Sons, Inc.; 2009. p. 491-510. http://dx.doi.org/10.1002/9781444312089.ch18

13. Salnikow K, Zhitkovich A. Genetic and epigenetic mechanisms in metal carcinogenesis and cocarcinogenesis. Nickel, arsenic, and chromium. Chem Res Toxicol 2008;21:28-44. http://dx.doi.org/10.1021/tx700198a

14. Klein CB, Leszczynska J, Hickey C, Rossman TG. Further evidence against a direct genotoxic mode of action for arsenic-induced cancer. Toxicol Appl Pharmacol 2007;222:28997. http://dx.doi.org/10.1016/j.taap.2006.12.033

15. Kumagai Y, Sumi D. Arsenic: signal transduction, transcription factor, and biotransformation involved in cellular response and toxicity. Ann Rev Pharmacol Toxicol 2007;47:243-62. http://dx.doi.org/10.1146/annurev.pharmtox.47.120505.105144

16. Kligerman $A D$, Tennant $A H$. Insights into the carcinogenic mode of action of arsenic. Toxicol Appl Pharmacol 2007;222:281-8. http://dx.doi.org/10.1016/j.taap.2006.10.006

17. Food and Agriculture Organization/World Health Organization. Evaluation of certain food additives and contaminants. International Programme on Chemical Safety. Geneva: WHO; 1983. (WHO Food Additive Report Series, no. 18).

18. Food and Agriculture Organization/World Health Organization. Evaluation of certain food additives and contaminants. International Programme on Chemical Safety. Geneva: WHO; 1989. (WHO Food Additive Report Series, no. 24).

19. Food and Agriculture Organization/World Health Organization. Evaluation of certain contaminants in food. Seventysecond report of the Joint FAO/WHO Expert Committee on Food Additives. Geneva: WHO; 2011. (WHO Technical Report Series, no. 959).

20. United States Environmental Protection Agency (US EPA). Integrated risk information system (IRIS) on arsenic. Washington, DC: National Center for Environmental Assessment, Office of Research and Development; 1998.
21. National Research Council. Arsenic in drinking water 2001 update. Washington, DC: National Academy Press; 2001.

22. Canada. Guidelines for Canadian drinking water quality. Guideline technical document, arsenic, water quality and health bureau. Health Canada: Ottawa, Ontario; 2006.

23. European Communities. Council Directive 98/83/EC of 3 November 1998 on the quality of water intended for human consumption. Official Journal of the European Communities L 330/32 EN, 5/12/98.

24. World Health Organization. Guidelines for drinking water quality. 2. Ed. Geneva: WHO; 1993.

25. World Health Organization. Guidelines for drinking water quality. 4. Ed. Geneva: WHO; 2011.

26. European Commission. Scientific Committee on Health and Environmental Risks, SCHER. Derogation on the drinking water Directive 98/83/EC. Adopted on 16 April 2010. Available from: http://ec.europa.eu/health/scientific_committees/environmental_risks/docs/scher_o_120.pdf.

27. World Health Organization. Vanadium. Environmental health criteria 81. Geneva: WHO; 1988.

28. World Health Organization. Trace elements in human nutrition and health. Geneva: WHO; 1996.

29. Wright MT, Belitz K. Factors controlling the regional distribution of vanadium in groundwater. Ground Water 2010;48:515-25. http://dx.doi.org/10.1111/j.1745-6584.2009.00666.x

30. Beyersmann D, Hartwig A. Carcinogenic metal compounds: recent insight into molecular and cellular mechanisms. Arch Toxicol 2008;82:493-512. http://dx.doi.org/10.1007/s00204-008-0313-y

31. European Food Safety Authority. Opinion of the scientific panel on dietetic products, nutrition and allergies on a request from the Commission related to the tolerable upper intake level of vanadium. EFSA J 2004;33:1-22.

32. National Toxicology Program, USA (NTP). Toxicology and carcinogenesis studies of vanadium pentoxide in F344/N rats and B6C3F1 mice (inhalation studies). (NIH Publication N. 03-4441). 2002; National Toxicology Program Technical Report Series, 507. 343 p.

33. Leopardi P, Villani P, Cordelli E, Siniscalchi E, Veschetti E, Crebelli R. Assessment of the in vivo genotoxicity of vanadate: analysis of micronuclei and DNA damage induced in mice by oral exposure. Toxicol Lett 2005;158:39-49. http://dx.doi.org/10.1016/j.toxlet.2005.02.009

34. Villani P, Cordelli E, Leopardi P, Siniscalchi E, Veschetti E, Fresegna AM, Crebelli R. Evaluation of genotoxicity of oral exposure to tetravalent vanadium in vivo. Toxicol Lett 2007;170:11-8. http://dx.doi.org/10.1016/j.toxlet.2006.07.343

35. Agency for Chemicals and Disease Registry. Toxicological profile for vanadium and compounds. Atlanta, GA: ATSDR, Department of Health and Human Services; 1992.

36. US Environmental Protection Agency (EPA). Inorganic contaminant accumulation in potable water distribution systems. Washington DC: Office of Ground Water and Drinking Water Standards and Risk Management Division; 2004.

37. Italia. Ministero della Sanità. Consiglio Superiore di Sanità. Sessione XLIII, Sezione III. Seduta del 18 gennaio 1995 su DPR. 236/88. Caratteristiche di qualità delle acque destinate al consumo umano. Eventuale fissazione della CMA al parametro 54-vanadio. Gazzetta Ufficiale (Suppl. Ord.) n.52, 3 marzo 2001.

38. Domingo JL, Llobet JM, Tomas JM, Corbella J. Short-term toxicity studies of vanadium in rats. $J$ Appl Toxicol 1985;5:418-21. http://dx.doi.org/10.1002/jat.2550050616

39. Domingo JL, Paternain JL, Llobet JM, Corbella J. Effects of 
vanadium on reproduction, gestation, parturition and lactation in rats upon oral administration. Life Sci 1986;39:819-24.

http://dx.doi.org/10.1016/0024-3205(86)90460-1

40. Klimisch HJ, Andreae M, Tillmann U. A systematic approach for evaluating the quality of experimental toxicological and ecotoxicological data. Regul Toxicol Pharmacol 1997;25:1-5.

http://dx.doi.org/10.1006/rtph.1996.1076

41. Italia. Ministero della Salute. Decreto 22 dicembre 2011. At- tuazione della direttiva 98/83/CE, relativa alla qualità delle acque destinate al consumo umano. Modifica del valore parametrico per il Vanadio. (11A16893). Gazzetta Ufficiale - Serie Generale n. 4, 5 gennaio 2012.

42. Boscolo P, Carmignani M, Volpe AR, Felaco M, Del Rosso G, Porcelli G, Giuliano G. Renal toxicity and arterial hypertension in rats chronically exposed to vanadate. Occup Environ Med 1994;51:500-3.

http://dx.doi.org/10.1136/oem.51.7.500 